\title{
ANNUAL REPORT OF THE COUNCIL
}

\author{
FOR 1883-4.
}

THE Council of the Sanitary Institute of Great Britain, in presenting their Seventh Annual Report to the Fellows and Mlembers, are much pleased to record that all the statistics in the Report show a larger increase in numbers than in any previous year, and that advance has been made in the objects of the Institute, besides the financial position being more firmly established.

By the kind permission of the Board of Managers, the Anniversary Meeting of the Institute was held in the theatre of the Royal Institution, on July 12th, 1883. The chair was taken by Prof. G. M. Humphry, M.D., F.R.s., Vice-President of the Institute; and the Medals and Certificates awarded at the Exhibition at Newcastle-uponTyne in September, 1882, were presented by him to the successful exhibitors. Mr. W. Eassie, c.E., F.L.s., F.G.s., read a paper on "The Relationship between Geology and Sanitation." The paper will be published in Vol. V. of the Transactions of the Institute.

At an ordinary Meeting held on July 24 th a paper was read by Prof. W. H. Corfield, M.A., M.D., on "The Compulsory Notification of Infectious Disease." The valuable matter relating to the working of compulsory clauses in those towns in which they are in force has been tabulated, and will appear in the Transactions (Vol. V.) The original returns, containing further information, are preserved in the Oflice for reference.

The Autumn Congress was held at Glasgow from September 25th to 29th, 1883, by invitation of the Lord Provost and Town Council, the President being Prof. G. M. Humphry, M.D., F.R.s. The Presi- 
dential and other addresses to the Congress, and the papers read at the Sectional Meetings, will be published in the Transactions (Vol. V.), together with abstracts of the discussions upon the papers. The London and Provincial Press contained very full accounts of the Meetings, and also commented most favourably upon the general work of the Iustitute.

Excursions and visits to places of interest were made during the Congress week.

The Exhibition was decidedly an advance even upon the satisfactory one held at Newcastle-upon-Tyne in the previous year. There were 130 exhibitors and 720 exhibits. The Judges awarded 18 Medals, 12 Special Certificates (to articles which had received Medals at previous exhibitions of the Institute), and 46 Certificates. Forty-four exhibits were deferred for further practical trial and testing, the result of these trials will be reported at the Anniversary Meeting in July, when all the Medals and Certificates will be presented. About 20,000 persons visited the Exhibition during the twenty-six days that it was open.

Candidates for Certificates of Competency to discharge the duties of Local Surveyors and Inspectors of Nuisances were examined in June and November. At the Examination in June eleven candidates presented themselves, four for Certificates as Local Surveyors and seven for Certificates as Inspectors of Nuisances. Two candidates were Certificated as competent to discharge the duties of Local Surveyors, and six as competent to discharge those of Inspectors of Nuisances. At the Examination in November ten candidates presented themselves, three for Local Surveyors and seven for Inspectors of Nuisances. One candidate was certificated as competent to discharge the duties of Local Surveyor, and five as competent to discharge those of Inspectors of Nuisances.

The Examinations are becoming very widely known, and the number of Candidates shows a steady increase. Besides the Local Boards and Corporations in England which recognise the value of the Certificates granted by the Institute, the influence of the Examinations is extending into Scotland, Ireland, and the Colonies.

During the year the Institute bas sustained the following losses by deatb:-Cromwell F. Varley, F.R.s., M.Inst.c.e., Fellow; Ralph Carr Ellison, and J. Laws, Members; and Matthew Pratt, Subscriber. 
Since the last Annual Meeting there hare been elected 4 Fellows, 41 Members, 14 Associates, and 2 Subscribers; and the numbers now on the Roll of the Institute are 90 Fellows, 213 Members, 34 Associates, 18 Subscribers, and 30 Honorary Foreign Associates -total, 385 .

The retiring Members of Council are Dr. B. Browning; James Mansergh, M.Inst.c.E.; Magnus Ohren, A.M.Irst.C.E.; Councillor J. A. Russell, м..., м.в. ; Henry C. Stephens, F.c.s. ; and J. Ure.

In September the Offices of the Institute were moved from Conduit Street to the Parkes Museum, 74A, Margaret Street; and although the Institute has not amalgamated with the Parkes Museum, their field of labour is so similar, that this association of Offices cannot fail to be beneficial to both. The Members of the Institute have the advantage of free access to the Museum and of the use of its Library.

In accordance with a suggestion made at the Congress, a Committee has been appointed by the Council for the purpose of considering the advisability of collecting and publishing in abstract the writings of the late Dr. William Farr, r.r.s., one of the Vice-Presidents of the Institute. The Committee has made considerable progress, and hopes soon to make a communication on the subject to the Members.

The Congress and Exhibition this year will be held in Dublin, an invitation from the representatives of the leading societies and the most prominent and influential residents in that city having been forwarded by Lord Brabazon, and accepted by the Institute. The Council trust that this Congress will prove as successful as the previous ones, and that the success of the meeting will, by assisting the cause of Sanitary Science in Ireland, promote the objects and interests of the Institute, and benefit the sister country.

$$
\text { (By Order) }
$$

E. WHITE WALLIS,

Secretary.

74a, Margaret Street,

7 th May, 1884 . 